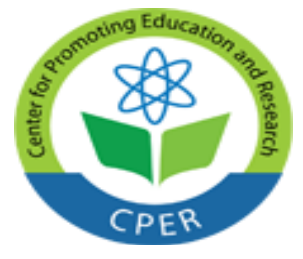

\title{
Traditional Industries of Bishnupur Sub-Division of Bankura District in West Bengal-A Survey
}

\author{
Dr.Tanay Kumar Pal \\ Associate Professor and Head \\ Department of Commerce \\ Dr. Gour Mohan Roy College \\ Monteswar,Purba Bardhaman \\ West Bengal, Pin-713145, India \\ E-mail: drtkpalcom@gmail.com \\ India \\ Dr.Uday Krishna Mittra \\ Associate Professor \\ Department of Commerce \\ Khalisani Mahavidyalaya,Khalisani \\ Chandannagar,Hooghly, W.B,India \\ E-mail: uday.mittra@gmail.com \\ India
}

\begin{abstract}
The present paper is concerned about important traditional industries of Bishnupur Sub-division Bankura District, West Bengal. It is based on the data and information collected from both primary and secondary sources. The authors have identified some problems faced by traditional industries and have also suggested some measures to be taken towards the development of the traditional industries of this area especially for the socio economic growth related to the rural development too.
\end{abstract}

\section{Introduction}

Bishnupur subdivision of Bankura District is mostly agricultural in nature. About $90 \%$ of the people of this sub-division are dependent on agriculture either directly or indirectly. But agriculture is dependent on the vagaries of nature. Irrigation facilities are not well developed. Productivity is also very low in the agricultural sector. The farmers have to depend upon alternative sources of income during their spare time when they do not have work in the farm sector. Cottage and small scale industries provide an ideal alternative source of income and employment for those who are dependent on agriculture. Cottage and small scale industries can use local resources and surplus manpower available. They also require relatively lower amount of capital funds.

The area has also a history of certain traditional cottage and small scale industries operating successfully with reputation. Notable among them are the units manufacturing Baluchari sarees and silk sarees. These sarees are now being sold all over India and even outside India with reputation. Further there are units producing conch shell products, bell metal products and handicrafts producing terracota objects, docra products and painting Das Avatar Tas. All these cottage and small scale industries have a glorious past and they are associated with this area for a very long period of time. Apart from these traditional cottage and small scale industries there are also modern small scale industries such as cold storages, rice mills, flour mills, engineering firms producing gates grills, ice cream manufacturing units etc. All these small scale industries play an important role in this subdivision. They can be a powerful alternative engine of growth generating income and employment. However, it is found that these cottage 


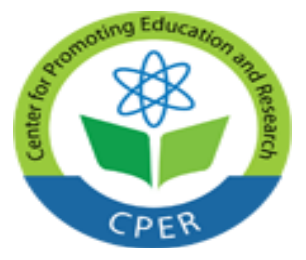

VOL: 5, ISSUE: 3

$\mathrm{March} / 2019$

E-ISSN: 2469-6501

(C) Center for Promoting Education and Research (CPER) USA

WWW.cpernet.org

and small scale units are facing some problems and they cannot contribute to their fullest extent in the process of economic development of the subdivision. Hence it is proposed that a study be undertaken to consider the position of cottage and small scale industries in the Bishnupur subdivision of Bankura district with special reference to the problems faced by them and the prospects they hold for the future.

\section{Objectives of the study}

(i) To assess the importance of traditional industries in the economy of Bishnupur sub-division in Terms of generation of income and employment.

(ii) To identify the problems faced by such units and to suggest solutions of those problems.

(iii) To suggest measures for improving the efficiency of such traditional industrial units.

\section{Sampling design, selection of reference year and collection of data}

There are 1948 registered cottage and small scale units in the Bishnupur sub-division. Besides, there are a number of non-registered cottage and small scale units. Primary data for the present study have been collected from 150 cottage and small- scale industrial units including 15 non-registered cottage and small scale units covering each block and taking all types of industries. Out of 1948 registered cottage and small scale units only 135 registered cottage and small scale units have been considered which is about $6.93 \%$ of the total registered cottage and small scale units lying in this sub-division. The survey has been conducted during the year 2012-2013. Purposive sampling method has been adopted for the selection of cottage and small scale units. Emphasis has been placed on tabular method for the analysis of primary data. Of the total 150 units primary data of 34 units from the block of Joypur, 21 units from Kotulpur, 39 units from Bishnupur , 16 units from Sonamukhi, 21 units from Patrasayer and 19 units from Indus have been collected. For the purpose of discussion, all the homogeneous industrial units lying in this sub-division have been divided under five categories:

1) Agro based Industries: Oil mills, wheat \& spice grinders, Rice mills, cold storage, flattened rice (Chira) mills and units making Thala Pata (Plates made of sal leaves).

2) Traditional arts and crafts: Baluchari sarees, Terracota, Handicrafts, weaver, potter, Bell metal, conch shell, painting Das Avatar Tas (cards depicting ten incarnations of Lord Vishnu).

3) Manufacturing Industries: Making gates \& grills, coke briquetting, printing, making candles, confectionary, Lantern, Readymade garments, spurt pipe, Tiles, R.C.C. ring pipe.

4) Service Industries: Xerox \& Type copying, photography-studio saw mills.

5) Seasonal Industry: Ice candy.

For the collection of primary data in this regard 47 Agrobased units, 39 Traditional arts \& crafts units, 42 Manufacturing industrial units, 8 Service Industrial units and 14 Seasonal industrial units have been selected. In this paper we have discussed on traditional arts and crafts only.

\section{Traditional Industries of Bishnupur}

Bishnupur sub-division is an essentially agricultural area. A study of the livelihood pattern of the population, as it was in 1961, reveals that about 77 per cent of the working population depended on agriculture, about 8.7 per cent depended on industry and the remaining 14.3 per cent depended on commerce, transport or other callings. Formerly, the principal industries were silk and cotton weaving with the main manufacturing centres located at 


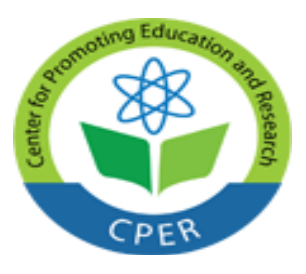

VOL: 5, ISSUE: 3

$\mathrm{March} / 2019$

E-ISSN: 2469-6501

(C) Center for Promoting Education and Research (CPER) USA

WWW.cpernet.org

Bishnupur and Sonamukhi. Other callings followed by traditional artisans included pottery making, brass and bellmetal work, cutlery manufacture, fabrication of conch-shell articles, leather work, preparation of scented tobacco and production of terracota plaques for temple decoration. Under the liberal patronage of the Malla kings of Bishnupur, the old time artisans attained a high degree of excellence in their craftsmanship. With the decline of the Malla Raj and the withdrawal of their patronage, the decay of old time industries started. The introduction of cheaper English piece goods towards the middle of the last century hit the weaving industry hard. The terracota and tobacco industries suffered an eclipse for want of patrons. Other handicrafts received a setback with the gradual increase in the cost of raw materials. The change in tastes also turned the buyers away from traditional products whose appeal had much to do with old-world associations. The introduction of mechanical and electric power in recent times led to the rise of such new industries as rice and oil milling and other industrial enterprises requiring cheap power. As there is no immediate scope for setting up of large scale industries in Bishnupur owing to the dearth of raw materials, absence of convenient markets nearby and lack of cheap transport etc. the only hope would seem to lie in resuscitating the traditional ones which could yet be viable under the present circumstances.

Large-scale industries like jute or textile industries, sugar factories etc. do not exist in Bishnupur. Small-scale industries have been in existence in this sub-division since the heyday of the Malla power. Some of them have been taken up for detailed enquiry.

Silk weaving is the most important among the old-time industries of the sub-division. In the $18^{\text {th }}$ and the early part of the $19^{\text {th }}$ century, Bishnupur played an important role in the commerce of the East India Company owing to the high appreciation of Bishnupur silks in foreign markets. Silk factories were located at Bishnupur, Joypur, Gopinathpur, Sonamukhi, Patrasayer, the chief centres being Bishnupur and Sonamukhi. Bishnupur enjoys a special reputation for the manufacture of prettily embroidered silk scarves, plain and flowered saris and a marooned coloured cloth called dhupchhaya. Sonamukhi specializes in shirtings and suitings of various pleasing designs while Bishnupur specializes in jacquard or plain bordered saris and mixed fabrics. In recent times Sonamukhi has been producing stout weaves of excellent quality capable of holding their own even in foreign markets. At present the main items of production are silk saris of ornamental design, dhotis, chaddars, tassar shirtings, matka and various other fabrics. The Bankura Resham Silpa Samabaya Sangha, a co-operative society of the silk artisans organized by the Directorate of Industries, West Bengal, plays an important role in the development of silk industry in the subdivision as well as in the district.

When in the past, the silk industry of Bishnupur was on the way of decline, many of the silk weavers of Bishnupur turned to rayon weaving as they found that rayon goods could be produced more cheaply and quickly. With an increasing demand for rayon products in the country, the artisans found the new calling remunerative although they had to import the yarns mainly from Japan or Italy. In 1965, a large number of families were employed in rayon weaving in Bishnupur producing, mainly, dhotis, saris, chaddars and shirtings which had a good market in West Bengal, Bihar and Orissa. Some of the producers have, in recent years, opened their own shops at Bishnupur from which middlemen collect the finished goods and despatch them to the selling centres.

In a report entitled "The State of the Tusser Silk Industry in Bengal and the Central Provinces" published in 1905, N. G. Mukherjee had stated, "Tusser weaving industry of Bishnupur seems to be more famous than that of any other place I have visited so far. The saris and dhotis of Sonamukhi and Bishnupur are very famous; even in Dacca and Mymensingh they are prized." He also stated that there were at that time 1000 families of tassar weavers at Sonamukhi, 500 to 700 families at Bishnupur, 400 families at Gopinathpur representing "at least 5,000 individuals working or capable of working in tusser. When they cannot get enough cocoons, they take to cotton weaving but they prefer turning out tusser. The tusser weaving industry of Bishnupur seems to be very extensive. The tusser weavers there weave either silk or tusser, more silk now than tusser. Silk weaving is improving while tusser weaving 


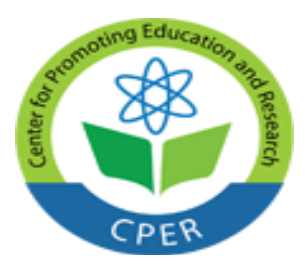

VOL: 5, ISSUE: 3

$\mathrm{March} / 2019$

E-ISSN: 2469-6501

(C) Center for Promoting Education and Research (CPER) USA

WWW.cpernet.org

is going down. The weavers say it costs them now almost as much turning out a tusser sari as a silk sari and people prefer a silk sari."

Cotton weaving has always been an important industry in Bishnupur. During the second half of the $19^{\text {th }}$ century, however, this cottage craft suffered a setback due to large imports of cheaper machine made cloth from abroad. The Second World War created a very good demand for handloom products owing to contemporary scarcity of mill-made cloths in the Indian market. This was reflected in the progress made by the industry in subsequent years. Towards the end of 1951, following a sharp fall in the demand for handloom products, the All India Handloom Board took active steps to reorganize the industries on proper lines. The official estimate, valid for March 1964, states that the co-operative societies had with them 5,266 registered looms while private weavers operated 6,839 looms in the district. Working on the figures accepted by the All India Handloom Board that each textile handloom employs on an average 2.5 persons, it is estimated that these 12,105 looms in the district provided employment to a little more than 30,000 weavers. With a view to placing the industry on the road to progress, the All India Handloom Board laid great stress on the formation of handloom weavers' co-operative societies. The main centres of cotton weaving in Bishnupur sub-division are located at Bishnupur, Sonamukhi, Patrasayer, Joypur and Madanmohanpur. The products are usually dhotis, saris, bed-sheets, napkins etc.

The principal centres of the conch-shell industry are located at Bishnupur town. At present there are relatively smaller artisans' communities at Bishnupur and Patrasayer engaged in the manufacture of conch shell ornaments like bangles, rings, bead-necklace etc. Occasionally, expert craftsmen turn out whole conch shell pieces exquisitely embellished with embossed decorations but such products do not find a market now and are, therefore, rarely produced. Rings, buttons and small floral designs are turned out of the parts that are left after the bangles have been sliced out. The polishing of the bangles and similar other minor works are done by the women and children in the artisan's family. The ornamentation is always done by the expert craftsmen with simple tools. Production and prices at most of the centres, of late, declined considerably. To the factory owners or independent workers, the margin of profit has become very small, while the incomes of the wage earning workers have been reduced with the result that the industry is becoming less and less remunerative. With a hired hand, a family of two working members can turn out 16 bangles a day, earnings from which can hardly sustain all of them. Shell bangles, once so popular in Bengal, particularly among married women, for their finish and design, now face serious competition from cheaper and more durable plastic wares, and in spite of their sentimental value to orthodox Hindus, shell bangles are being gradually pushed out. According to expert opinion, resuscitation of this exquisite cottage industry could be brought about through the provision of better capital, arrangements for regular supply of quality shells at reasonable prices as also in the improvement and change in the designs.

Brass and bell-metal utensils and various other articles are manufactured on a large scale at Bishnupur, Sonamukhi, Patrasayer, Ayodhya and Madanmohanpur. A special alloy, called bharan, is used only by the artisans of Bishnupur. Bishnupur specializes in producing plates, bowls, tumblers etc. The plates are of various kinds, namely chhak katki, nath katki (which show intricate floral decorations on the raised edges as also at the Centres), monohara, kanseswari etc.

The measuring bowls of Bishnupur also have various names according to their cubic contents. These may be sholo-charti, aat-charti or Panch-charti according to their respective capacities for measuring 16, 8 or 5 units. The mota-poa and khas-poa bowls can measure up quarter to a seer. The dari-bati (having a tapering end and an expanded bottom), the chikan and the talajuri are other kinds of bowls. There are at least two types of bowls manufactured at Bishnupur which are associated with place names, namely Lakskmisagar-bati and Kaliganjer-bati. Another type of bowl, bearing the name Padma-bati, finds a ready market in Orissa. The articles usually turned out at Patrasayer are cups and lotas, mostly of brass. They are cast in moulds and the methods of turning and finishing are similar to those employed at Bishnupur. Brass or pital is a mixture of copper and line; bell-metal or kansa is 


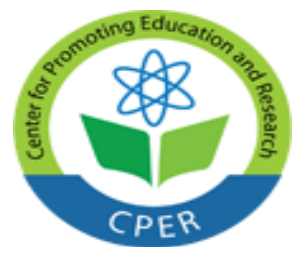

VOL: 5, ISSUE: 3

$\mathrm{March} / 2019$

E-ISSN: 2469-6501

(C) Center for Promoting Education and Research (CPER) USA

WWW.cpernet.org

obtained by fusing copper with tin and bharan is prepared by mixing copper, zinc and tin. The art of mixing the ingredients has come down to the artisans as a hereditary skill which they try to keep as a trade secret. Of these three alloys, Kansa is the most popular, pital and bharan following it in that order. A quantity of German-silver goods is also produced at Bishnupur.

At present there are 15 brass and bell-metal establishments in Bishnupur, all owned by the members of 4 families who use the titles 'Das', 'Kaiti', 'Kuchlyan' and 'Chakravarti' as their surnames. The Das, Kuchlyan and Kaiti families come from the Karmakar caste, a section of the Nabasakha group, from whose hands a Brahmin may take water. The Chakravartis are Brahmins but they took to this profession long ago. The owners of these workshops usually employ paid artisans, mainly from the Karmakar caste.

The principal centres of pottery industry are located at Sonamukhi and Bishnupur. It was found that inexpensive ingredients like common earth and sand were the principal raw materials used in this industry. These raw materials were either gathered free or collected from rented lands or procured from other sources at varying prices. Transport and labour charges were the two principal factors determining the cost of supply of these items. Nearly all the sand was obtained by the artisans free of cost. The products consist mainly of various types of pots and pitchers, tumblers, plates and the like, which are turned out on the potter's wheel and then sun-dried and burnt in kilns. Slips are used on the finished products some of which are also decorated with simple designs. The brittleness of the manufactured articles does not permit their export to distant places and these are mostly sold in the vicinity of the potters' village.

The future of this industry does not appear, on the whole, to be bright. Competition from utensils made of cheap materials like aluminium etc. is difficult to overcome as these durable substitutes have now penetrated into the remotest rural areas. Insufficiency of capital, non-availability of fuels at reasonable prices and lack of marketing facilities are also formidable obstacles.

Lantern industry is mainly located at Bishnupur. A special variety of cheap lanterns is produced at Bishnupur of which the prototype was fabricated some 80 years ago by one Rai Charan Garai, a member of the Kolu community residing at Bishnupur. Because of their dependability, extreme cheapness and low kerosene consumption these lanterns are very popular among the poorer sections of the people. The industry is mainly in the hands of the members of the Kolu caste who reside in the Aisbazar, Raghunathsayer, Gopalganj, Hazrapara, Bahadurganj, Garhdarja and Station Road localities of Bishnupur' town. Of the 55 workshops now in operation, they own some 50, the rest being run by members of the Sutradhar and Karmakar castes. As is common in all cottage industries, the members of the owners' families help in the process making it largely unnecessary to employ hired labour unless the establishment is big. The largest unit of the Bishnupur lantern factories employ 20 paid workers and produce, on an average, 144 lanterns a day. Raw materials used in the industry are galvanized sheets, plate glass, wire and tin foils. In 1965 the cost of production varied between $\mathbf{0 . 7 5}$ rupee and Re. 1 and the selling prices were from Re. 1 to Rs. 1.50 per piece. The wholesale prices were from Rs. 11 to Rs. 16 per dozen. These lanterns find a wide market all over Bankura, Midnapore, Burdwan, Birbhum and Purulia and are also exported to places as far away as Bilaspur in Madhya Pradesh and Mathura in Uttar Pradesh. The condition of the industry is, on the whole, satisfactory owing to the heavy off take of its product. The industry was virtually a monopoly of Bishnupur but of late workshops have come up at Rampurhat (Birbhum district) and Katwa (Burdwan district) but these do not pose any problem for the industry at Bishnupur.

\section{Problems of Traditional Industries}

Let us consider the specific problems faced by traditional industrial units which are operating in this subdivision. 


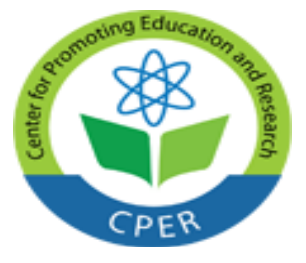

VOL: 5, ISSUE: 3

$\mathrm{March} / 2019$

E-ISSN: 2469-6501

(C) Center for Promoting Education and Research (CPER) USA

WWW.cpernet.org

(i) The scarcity of finance and credit is the main obstacle in the way of development of traditional industrial units in this sub-division. The capital base of the traditional industrial units is usually very weak since they generally are of the nature of partnership single ownership. The artisans or craftsmen running traditional industries either run their businesses with whatever little capital they possess or take credit from mahajans or village money lenders or traders who supply raw materials to them. In many cases such credit is obtained at a very high rate of interest and is thus exploitative in character. However, the profit earned by them is often not enough for investment purposes.

(ii) Another problem faced by traditional industrial units is in respect of the availability of raw materials. The majority of the traditional units depend on local sources for their raw material requirements. The handloom industry depends for its requirement of cotton thread on local traders. These traders often supply cotton on the condition that the weavers would sell clothes to them when they are ready. Thus the weavers are subjected to double exploitation in the hands of the traders. The traders sell cotton thread to them at high prices and purchase the ready clothes at low prices.

(iii) Machinery and other equipment's in many traditional industrial units have become obsolete. On account of this reason while their costs of production are high, the quality is inferior as compared to the large-scale units. Moreover, the traditional units often do not care about the changing tastes and fashions of the people.

(iv) Another problem faced by traditional units is competition from other units. There are more than 10 to 12 same type of units in a block. So they have to face a stiff competition.

(v) One of the most difficult problems of the traditional entrepreneur today is labour. Labourers today are fully aware of their rights. They demand facilities like Government employees.

(vi) Raw materials in conch shell units have to be collected from Kolkata. Sometimes it is found that raw materials contained in the bag are defective. As a result, they have to incur heavy loss.

(vii) 'MANJUSA'-West Bengal Handicrafts Development Corporation does not want to procure the finished products of terracota and handicraft units all the time. Sometimes their payment period is too late.

(viii) Political interference is observed in the case of some units for getting loan and financial assistance.

(ix) The design which is used in the Baluchari saree has to be bought from the market at a high price as this design is prepared by a few persons.

(x) In addition to the problems enumerated above, the cottage and small scale industrial units face a number of other problems like inefficient management, frequent power cut, lack of skilled technicians and burden of local taxes etc.

Problems of traditional industries are multi-dimensional. These can be solved by the co-ordinated efforts of entrepreneurs, the co-ordinated functioning of promotional agencies and governmental assistance without red tape or bureaucratic delays. The entrepreneur has to be educated and he should have proper training in acquiring the necessary skills in running a small enterprise. In fact, the small entrepreneur is the king-pin of the traditional industry.

\section{Suggestions for improvement}

In the light of the above discussions, some suggestions may be put forward for the future improvement of the traditional units in this sub-division.

(i) The traditional entrepreneurs are required to move from pillar to post to meet different agencies like IDO, DIC, Panchayat and banks etc. for the sanction and early implementation of their projects. This causes a lot of strain and stress to them. To save time and hassle the DIC should maintain a close liaison with all 


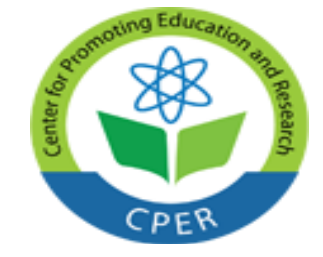

VOL: 5, ISSUE: 3

$\mathrm{March} / 2019$

E-ISSN: 2469-6501

(C) Center for Promoting Education and Research (CPER) USA

WWW.cpernet.org

other concerns involved in the process and take the entire responsibility of clearing the project as soon as possible. Perhaps, the DIC should be strengthened with skilled staff to meet the specific needs. Cooperation and co-ordination between the Banks and the DIC should also be improved.

(ii) DIC should assure the supply of scarce inputs on quota basis at subsidized rates so that the small entrepreneurs carrying on traditional industrial units are saved from the exploitation of the middlemen.

(iii) Marketing is an important factor, particularly in case of traditional units producing goods and services. It will be simply disastrous if the products or the services fail to find sustained and steady market which not only spells financial loss but also leads to eventual closures of the units. For the survival of these small units the Government should create marketing facilities through different channels like 'Tantuja', 'Tantushree', 'Manjusa' which purchase the products of traditional units. Also payment made by such channels to the traditional units should be as quickly as possible so that the production process of the traditional units can continue without any interruption. Besides, different Government and QuasiGovernment sectors should give due preference to traditional goods and services while placing their orders.

(iv) It is advisable to clear the projects at an early date keeping in mind the continuous price hike of inputs, machinery and other equipment's so that it is possible for the entrepreneurs to purchase the same with their limited investible funds.

(v) In order to serve the technical needs and to improve their entrepreneurship qualities a sound training programme is urgently needed for the some units. It would be better if a single training Centre under the roof of the DIC is established.

(vi) With the persistence of inflation in the country, the maximum ceiling of subsidy at present Rs. 10,000 provided by Bengal State Aid to Industries to some poor artisans at village level through DICs should be enhanced. Considering the genuine demands, more finance should be facilitated to large number of poor artisans with relaxation of terms and conditions.

(vii) As there is no insurance cover some entrepreneurs are found incurring losses on account of theft and fire. The entrepreneurs should be encouraged to become insurance-minded so that they realize that with incurring a paltry amount towards insurance premium the possibility of huge losses can be avoided.

(viii) It is advisable that Government should make arrangements through DIC by which spare parts are available all the time in the district.

(ix) For better functioning of traditional units and to overcome their financial position more capital is needed by them. In this regard banks should come forward and more finance should be given to the small entrepreneurs. There should be all-out efforts on the part of Block and Panchayat level officials to help the banks in the matter of recovery of past loans. There must be political will on the part of Panchayats for this purpose.

(x) Government should employ such persons as IDOs at block levels who will be well equipped with training and having technical knowledge by which they would have a good idea about various traditional units. 


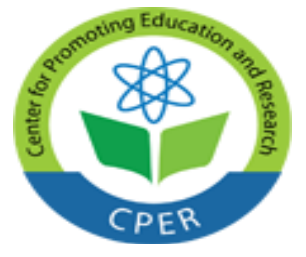

VOL: 5, ISSUE: 3

$\mathrm{March} / 2019$

https://ijbassnet.com/

E-ISSN: 2469-6501

(C) Center for Promoting Education and Research (CPER) USA

wWW.cpernet.org

(xi) For entrepreneurship development and for prospective traditional entrepreneurs, Government should arrange seminars and awareness camps regarding traditional industries with the help of DIC and Block and Panchayat level officials.

(xii) For smooth functioning of traditional units, Government should improve the position regarding the supply of electricity.

(xiii) To meet the changing demands of the local customers as well as on the part of the tourists, some units like Baluchari units, terracota, handicrafts and conch shell should change their products accordingly.

(xiv) The State Govt. should make arrangements for the exhibition of Baluchari sarees, terracota handicrafts in other provinces so that traditional units will be able to enjoy larger market.

\section{REFERENCES:}

Banerji, Amiya Kumar,"West Bengal District Gazetteers, Bankura,"State Editor, West Bengal District Gazetteers,Calcutta,1968.

Bhattacharyya,Amarsankar,”Mauna Mukhar Bishnupur,"( in Bengali), Mitra \&Ghosh Pvt. Ltd., Calcutta,2000.

Chattopadhyay, Haridas,"Bankurar Itibritta," ( in Bengali) Gyan Prakashani,Calcutta,1999.

Dasgupta,Chittranjan,”Bishnupurer Mandir Terracota,” (in Bengali ) Dasgupta \&Co. Pvt. Ltd.,Bankura,1975.

Desai, Vasant," Organisation and Management of Small Scale Industries," Himalaya Publishing House, Bombay, 1983.

Desai, Vasant, "Problems and Prospects of Small Scale Industries,"Himalaya Publishing House, Bombay, 1983.

Hunter,W.W,” The Imperial Gazetteer of India,” Trubner \& Co., London, 1881.

O’ Malley, L.S.S,” Bengal District Gzetteer , Bankura,” Bengal Secretariat Book Depot, Calcutta, 1912.

Tandon,B.B and Tandon, K.K, "Indian Ecinomy,” Tata MCGraw -Hill Publishing Co. Ltd., New Delhi, 1997.

Sharma,G.R, "NABARD,SSI \& Cottage Sector," in Laghu Udyog Samachar, May 1990, Vol.XIV, No.10, PP 3-7. 